\title{
11 \\ TREASURY EFFICIENCY OF THE CANADIAN TAX REGIME FOR PRIVATE FOUNDATIONS AND THEIR FOUNDERS
}

\author{
Brigitte Alepin
}

\section{Introduction}

In November 2020, the OECD released its most important report on taxation and philanthropy, and in it, the organisation strongly suggests that countries "conduct studies that evaluate the efficiency" of their incentives that subsidise philanthropy. This suggestion takes on even greater importance when one considers that the COVID-19 pandemic has caused the worst global economic crisis since the Great Depression and that in order to get through the crisis, all countries are currently in debt and the needs are glaring in several public sectors, particularly in health, social services and education. These are sectors to which several private charitable foundations have dedicated their purpose in the past.

Private foundations hold about $\$ 1$ trillion worth of assets in North America, and that figure continues to grow every year. Even as urgent needs go unmet with the COVID-19 crisis, private foundations continue to spend only a tiny fraction of their wealth on charities, mostly due to the tax laws that permit and encourage this build-up of philanthropic wealth. In Canada, founders can take a full tax credit of a maximum of $57 \%$ of the value of their donation in the year of the creation of the foundation, while at the same time, that foundation can invest that money tax free forever and never spend its capital on charity.

Philanthropy is on the rise, and although many of its facets could be discussed further, the basic question in this chapter is to assess whether the tax incentives that private charitable foundations and their founders may benefit from in Canada are treasury efficient. In other words, are they a good or fair deal for Canadian taxpayers? The Canadian tax regime is studied because it is one of the most advantageous tax regimes for private foundations and their founders among the G7 countries. This chapter concludes that the tax regime in Canada is not efficient as it presently exists, with a disbursement quota of $3.5 \%$, a full tax holiday for the foundation and a tax incentive that may reach as high as $57 \%$ of the donation for the founder. To become treasury efficient within 20 years, it is demonstrated that the disbursement quota should be increased to $5.5 \%$.

The chapter is organised as follows. In the next section, the tax incentives that private charitable foundations and their founders may benefit from in Canada are explained. In the second section, the theoretical framework for analysing the treasury efficiency of these incentives is 
analysed. The last section establishes the necessary facts and reasonable assumptions for the evaluation and concludes with the calculation of the treasury efficiency of the tax regime regarding private foundations in Canada.

\section{Tax incentives that private charitable foundations and their founders may benefit from in Canada}

Tax incentives towards charitable giving have existed in Canada for over 100 years. The policy has been significantly modified over time, and the last major review of the tax regime regarding private foundations in Canada dates back almost 50 years.

The first tax deductions for charitable donations were introduced to finance the First World War through the creation of wartime relief funds. The Income War Tax Act (IWTA) of 1917 instituted unlimited tax deductions for all donations, primarily to the Canadian Patriotic Fund (CPF) as well as to the Canadian Red Cross (CRC) Fund.

With a 1930 amendment to the 1917 IWTA, the federal government defined the first official foundations on which charitable activities would operate on Canadian soil. Establishing the rules and obligations governing tax deductions for charitable donations, this amendment designated the Ministry of Finance as the regulator of the sector (Elson 2010).

Until the First World War, no major foundation had been created in Canada, and it was not until the end of the war that the Massey Foundation was created in 1918 (Granatstein and Kucharsky 2008). In 1976, as part of a broader tax reform flowing from the Royal Commission on Taxation (Carter Royal Commission), the obligation for the foundation to allocate at least $5 \%$ of its assets annually to charitable organisations and activities was introduced in the Income Tax Act. These rules were designed to ensure that tax-receipted charitable gifts were applied for the benefit of charities and not simply held in investment accounts (Bourgeois 2010: 184). Today, the law is essentially the same, but the charitable obligation has been lowered to $3.5 \%$.

\subsection{Tax incentives for the founder}

The giving incentive for the founder is designed to support charities that serve the needs of the people. The tax treatment of the donation varies whether the donation is being done by an individual or a corporation.

Individuals: Until 1988, the incentive was a tax deduction, and the tax credit was introduced in Canada in 1988 for individual donors. An individual who has income taxed the maximum marginal rate may benefit from a tax credit of $57 \%$ of the donation, taking into consideration both federal and provincial taxes. The federal government limits monetary donations to be included in the calculation of a tax credit to $75 \%$ of the taxpayer's net income, and any unused credit balance can be carried over for a period of five years.

When capital property is donated, there is a disposal at fair market value (FMV) for tax purposes, which may result in a capital gain, and this FMV represents the donation for tax purposes. Capital gains can be eliminated by donating certain types of capital property such as certain securities listed on a stock exchange in Canada (shares, debt, participation in a mutual fund trust or in a segregated fund trust, etc.).

Corporations: Donations to a registered charity made by a corporation are deductible from its taxable income, which will result in a reduction of the corporation's tax liability. In addition, there are additional tax incentives when publicly traded securities are donated. As in the case of individuals, the federal government limits monetary donations to be included in the calculation 
of the tax credit to $75 \%$ of the corporation's net income, and any unused credit balance can be carried over for a period of five years.

Without underestimating the importance of donations made by corporations, only donations made by individuals are analysed in this research because they represent by far the largest source of charitable donations made in Canada.

\subsection{Tax incentives for private foundations}

In Canada, organisations dedicated to charitable purposes and that are registered with the Canada Revenue Agency can issue donation receipts and are tax exempt.

A private foundation in Canada is established as a corporation or a trust. It has only charitable purposes and carries on its own charitable activities, and/or it funds other qualified donees. More than $50 \%$ of the foundation's directors deal with each other at arm's length and/or $50 \%$ or more of the foundation's funding comes from a person or group of persons that control the charity in some way [Income Tax Act, 149.1(1)].

Private foundations must file financial statements with the prescribed information form T3010 annually to the Canada Revenue Agency. The top sectors for private foundations in Canada are health, education and social services (Philanthropic Foundations Canada 2017).

Private foundations have to spend $3.5 \%$ of their capital annually on charitable activities or gifts to qualified organisations. There was a time in Canada when the "disbursement quota" imposed on charitable foundations was higher than 3.5\%. According to Finance Canada's 2004 budget,

analysis indicates that the current $4.5 \%$ disbursement quota is high relative to longterm investment returns. Accordingly, the budget proposes to reduce the $4.5 \%$ disbursement quota on capital assets to $3.5 \%$. This rate will be reviewed periodically to ensure that it continues to be representative of long-term rates of return.

The reduction in the disbursement quota allows Canadian foundations to keep their start-up capital and ensure that their foundations last indefinitely.

The annual expenses of the foundation are considered in the calculation of the disbursement quota, and generally, the annual expenses of foundations range from $0.75 \%$ to $1.5 \%$ of their assets (Philanthropic Foundations Canada 2015).

Private foundations cannot engage in any commercial activities, and a private foundation that owns more than $20 \%$ of a class of shares of a corporation's stock faces a penalty of $5 \%$ of the FMV of those excess shares, and its registration can be revoked.

Tax incentives for private charitable foundations and their founders, in general: In short, in Canada, the regime grants a donation credit to the founder that can reach $57 \%$ of the donation in the year of the donation, regardless of when the money will be spent by the foundation. The foundation benefits from a total tax holiday, and its annual charitable obligation is limited to $3.5 \%$ of its capital. Compared to G7 countries (see Table 11.1), Canada offers one of the most generous tax regimes to private foundations and their founders.

\section{How to measure the "treasury efficiency" of the tax incentives that private charitable foundations and their founders may benefit from?}

There has been a lot of research into the efficiency of the tax incentives in philanthropy, but most of it has concentrated on the tax credits or deductions for giving. There has been less 
Table 11.1 Tax regime for private foundations and their founders among the G7 countries

\begin{tabular}{|c|c|c|c|c|}
\hline Country & $\begin{array}{l}\text { Maximum tax exemption/tax } \\
\text { credit for founder }\end{array}$ & $\begin{array}{l}\text { Foundation: } \\
\text { tax holiday on } \\
\text { income }\end{array}$ & $\begin{array}{l}\text { Foundation: annual } \\
\text { distribution obligation } \\
\text { on the income }\end{array}$ & $\begin{array}{l}\text { Foundation: annual } \\
\text { distribution obligation } \\
\text { on the capital }\end{array}$ \\
\hline Canada & $\begin{array}{l}\text { Tax credit of } 57 \% \text { maximum, } \\
\text { subject to limitation of } \\
75 \% \text { of income }\end{array}$ & Yes & No & Yes, $3.5 \%$ annually \\
\hline France & $\begin{array}{l}\text { Income tax reduction for } \\
66 \% \text { of the value of the } \\
\text { gift ( } 75 \% \text { for specific } \\
\text { donations), up to } 20 \% \text { of } \\
\text { the donor's taxable income }\end{array}$ & Yes & No & No \\
\hline Germany & $\begin{array}{l}\text { Tax deduction up to } \\
20 \% \text { of the taxable } \\
\text { income, or donations } \\
\text { to a foundation can be } \\
\text { deducted up to an amount } \\
\text { of up to } € 1 \text { million for an } \\
\text { assessment period of up to } \\
10 \text { years }\end{array}$ & Yes & $\begin{array}{l}\text { Yes, income has to } \\
\text { be distributed } \\
\text { within } 2 \text { years }\end{array}$ & No \\
\hline Italy & $\begin{array}{l}\text { Donations to ONLUS are } \\
\text { deductible up to } 10 \% \text { of } \\
\text { income with a maximum } \\
\text { of } € 70,000 \text {. Alternatively, } \\
\text { tax credit of } 26 \% \text { for } \\
\text { donations to ONLUS and } \\
\text { other kinds of charities, up } \\
\text { to the value of } € 30,000\end{array}$ & No & $\begin{array}{l}\text { Yes for foundations } \\
\text { of banking origin: } \\
\text { at least half of the } \\
\text { profits of the year } \\
\text { must be granted } \\
\text { in the following } \\
\text { years. Other: } \\
\text { Yes, within a } \\
\text { reasonable period } \\
\text { of time }\end{array}$ & No \\
\hline Japan & $\begin{array}{l}\text { The donor claims a tax credit } \\
\text { or a deduction up to } 40 \% \\
\text { of its income }\end{array}$ & Yes & No & No \\
\hline $\begin{array}{l}\text { United } \\
\text { Kingdom }\end{array}$ & $\begin{array}{l}\text { The donor claims a } \\
\text { deduction from taxable } \\
\text { income or capital gains } \\
\text { for the amount of the } \\
\text { donation grossed up by the } \\
\text { basic rate of tax }(20 \%)\end{array}$ & Yes & $\begin{array}{l}\text { Yes, income has to } \\
\text { be spent within a } \\
\text { reasonable period } \\
\text { of time, generally } \\
\text { accepted as } 3 \text { years }\end{array}$ & No \\
\hline $\begin{array}{l}\text { United } \\
\text { States }\end{array}$ & $\begin{array}{l}\text { Tax deduction up to } 60 \% \\
\text { or } 30 \% \text { of adjusted gross } \\
\text { income depending on the } \\
\text { beneficiary }\end{array}$ & $\begin{array}{l}\text { No, tax on } \\
\text { investment } \\
\text { income }\end{array}$ & No & Yes, 5\% annually \\
\hline
\end{tabular}

research into the efficiency of the global tax regime that may benefit private foundations, including the incentives for giving, the tax holiday for the foundation and the design of the disbursement quota.

This section analyses how to measure the treasury efficiency of private foundations. Before doing so, the treasury efficiency of the tax incentives of giving will be briefly reviewed to see if 
it is a good idea to fiscally encourage giving. If it would not be a good idea to begin with, then there would be no point in carrying the analysis further.

After, how to measure the treasury efficiency of private foundations' tax systems as a whole is analysed. This requires questioning the necessity of discounting the future value of the charity made by the foundation over the years and whether the cost of the tax holiday that benefits the foundation should be considered.

\subsection{Treasury efficiency of the tax credit/deduction on the donation}

The treasury efficiency suggests that the revenue losses to the treasury resulting from the tax incentives are equalled or exceeded by the value of the funds generated for public purposes through the incentives (Simon 1987: 72). In terms of tax incentives for giving, the treasury efficiency means that money raised by the tax exemption/credit exceeds the cost for the treasury in foregone revenue.

To reflect on this, it is therefore necessary to analyse the elasticity of giving. The demand for a product is considered inelastic with respect to the price if the percentage of change in quantity demanded is less than the percentage change in price (the elasticity is less than 1). And the demand for a product is said to be elastic with respect to the price if the percentage change in quantity demanded is greater than the percentage change in price (the elasticity is greater than 1).

In terms of tax policy, if the price elasticity of a tax incentive is greater than 1 , it means that the taxpayers who claim tax deductions/credit for charitable contributions are likely to increase their giving by more than the estimated revenue cost of the subsidy. In such a case, the subsidy would be said to be "treasury efficient." If the elasticity is smaller than 1.0, the extra giving prompted by the charitable deduction is less than the revenue cost for the public finances and it is said to be "treasury inefficient."

Several experts have investigated the price elasticity of giving, and unfortunately their estimates vary greatly. In 1985, Charles Clotfelter found that the price elasticity for the population of taxpayers was probably greater than -1 (with a range of -0.9 to -1.4 ). In 1995, William C. Randolph used different methodologies and concluded differently, with a much lower price elasticity (Randolph 1995: 710). In 2005, John Peloza and Piers Steel concluded, after an analysis of 40 years of research, that tax deductions were treasury efficient (Peloza and Steel 2005: 269). Peter G. Backus and Nicky L. Grant concluded in 2019 that the top 10\% of income earners had an elasticity of at least -1 and middle-income earners had a lower price elasticity (Backus and Grant 2019: 319).

Thus, after 100 years of using the tax system in different countries to encourage giving, it is still unclear if effectively, these tax policies have proved to be efficient or not. What about when these donations are given to private charitable foundations, which often withhold them, thereby paying no tax ever? Is the global tax regime for private foundations and their founders treasury efficient?

\subsection{Treasury efficiency of the tax regime for private foundations and their founders}

Let's return to the definition of treasury efficiency, which suggests that tax exemption is efficient if the revenue losses to the treasury resulting from the exemption are equalled or exceeded by the value of the funds generated for public purposes through the exemption (Simon 1987: 72). 
Translated into the foundation context, the tax regime of the foundation is efficient and appropriate as long as it ensures that future grants distributed by the foundation exceed the deductions/credits given to the donor (Toepler 2004: 736).

Since these grants distributed by the foundation are made most of the time in the future, and the foundation does not pay tax in the meantime, two questions need to be answered in order to be able to calculate the treasury efficiency of a foundation:

Should a present-day discount of future grants be considered?

Should the cost of that tax holiday, in terms of public revenues lost, be considered?

\section{Should present-day discounts of future grants be considered?}

This question has been analysed mainly by American experts. In 1965, the United States Treasury Department and Congress were troubled by the fact that a donor to a foundation takes a tax deduction at the time of the donation, but the donated funds might not reach actual operating charities until many years later. Congress and the Treasury believed that because of this delay, donors were getting a tax benefit worth more than the charitable benefit they produced. In other words, they thought there was a mismatch between the value of the tax deduction and the value of charity given in the future. In the Treasury report on foundations submitted to Congress in February 1965, the United States Treasury Department stated that:

The tax laws grant current deductions for charitable contributions upon the assumption that the funds will benefit the public welfare. This aim can be thwarted when the benefits are too long delayed.

In such cases there is usually a significant lag between the time of the contribution, with its immediate effect upon tax revenues, and the time when the public benefits by having an equivalent amount of funds devoted to charitable activities.

Several elements in these two quotes show that the Treasury Department recognises that a dollar given today to charity does not have the same value as a dollar given in the future, including the fact that the Department chooses the word "equivalent" and not "equal" to compare the value of the tax savings resulting from the donation with the value of the charity created by the foundation in the future. This problem was addressed by introducing a $5 \%$ charitable obligation into tax law, requiring U.S. foundations to spend at least $5 \%$ of their capital on charity each year.

In 2002, McKinsey \& Company experts Paul J. Jansen, David M. Katz and Bill Bradley also recognised the need to consider present-day discounts of future grants. They argued that we should view foundation grants as an investor would view an investment. In other words, just as investors would choose to receive a dollar today rather than a dollar a year from now, a dollar of charity given today is worth more than a dollar of charity given in the future.

The McKinsey team refer to what is being done in the business world when an investment is considered. To decide if the business should invest in a project or not, the present value of its future returns is calculated by discounting those returns at a certain rate to reflect the time value of money, and the project is considered only if those returns have a present value that exceeds its initial cost.

Thus, for the McKinsey team, the business concept of "discounting" should be applied by foundations to evaluate what is best between investing in a social project today or investing the money for future projects. However, as Jansen and Katz explain, "Applying this methodology to 
non-profits is admittedly complicated, since their return on investment accrues to society rather than to the donor and comes in the form of hard-to-quantify social benefits" (2002).

In 2003, Professor Michael Klausner brought an important clarification to the reflection to the effect that donations today are not necessarily worth more than donations tomorrow simply because of the time value of money. He said, "there are good reasons for foundations to favour high payout rates under certain circumstances, and there may be reasons for the law to mandate minimum payout rates, but the time value of money is not one of them" (Klausner 2003: 54).

Professor Klausner supports his theory by explaining that in reality, delayed spending by the foundation does not cost anything, since future charity benefits from compound growth, and therefore, "receiving 34 cents today and receiving $\$ 241$ in 48 years are equivalent." Thus, assuming that the foundation's assets are invested as profitably as the government's money would have been, Klausner supports the conclusion that the delay does not reduce the present value of the government's subsidy via the deduction/credit allowed on the donation in the first place (Klausner 2003: 53).

From that perspective, when we compare a grant to charity today with one made in 48 years' time, we are in fact comparing the benefit of helping one group of people today with the benefit of helping another group in 48 years. By invoking the discounted cash flow approach, Professor Klausner explains that it is similar to adopting what economists refer to as a "pure time preference" in allocating resources over generations. If future grants are discounted to present value, Klausner explains that it is the same thing as saying that "future people's lives are less important simply because [they] live at different times." (Klausner 2003: 54).

Even if Professor Klausner brought this important nuance in relation to the value of money over time, he does not reject the idea that it is necessary to analyse "how cost-effective a grant to current charity would be, compared to future charity." Doing otherwise would cheat future generations as much as it would cheat present-day taxpayers (Klausner 2003: 57).

In 2009, David A. Weisbach and Cass R. Sunstein also recognised that we can value future and present lives equally and still want to consider the government's opportunity cost. By applying a market discount rate, in effect, we are asking, "Which project would produce more wealth for the future: funding this project or investing the money?" If the project would pay less than an investment would, how does it serve the future to fund the project? (Weisbach and Sunstein 2009: 449).

In 2016, Professor Brian Galle reiterated in his article "Pay It Forward? Law and the Problem of Restricted-Spending Philanthropy" that, "present value is and must be a key part of serious policy analysis." He explained that to justify government support for restricted spending, foundation savings should have to beat two benchmarks. First, the utility payoff to future spending - net of all the costs and benefits that delay might bring - should exceed the government's investment opportunity: when the government gives foundations a dollar, the utility of future spending should equal or exceed the utility we could get from a dollar of present spending. Second, the net payoff should exceed any returns that the foundation could achieve by spending now on projects whose useful life is expected to be just as "perpetual" as the foundation itself (Galle 2016: 1159).

In conclusion, the topic of how time and value interact in philanthropy is important and, somewhat surprisingly, "remains under-explored and under-analysed over time". ${ }^{1}$ Despite Professor Klausner's inevitable finding that delayed spending by the foundation does not cost anything, since future charity benefits from compound growth, and therefore, "receiving 34 cents today and receiving $\$ 241$ in 48 years are equivalent," a comparative analysis is nevertheless 
necessary in order to evaluate "how cost-effective a grant to current charity would be, compared to future charity" (Klausner 2003: 54). In other words, as Professor Galle explains,

it is important to consider whether the future payoffs that a restricted-spending foundation can deliver are better than the alternatives of unrestricted spending, or of eliminating the government's subsidy and investing that money for some other kind of future spending instead.

(2016: 1159)

\section{Should the cost of that tax holiday for the foundation, in terms of public revenues lost, be considered?}

Investment income is normally taxable income, and therefore, its exemption from tax should be considered a subsidy, even if earned by a charity (Hansmann 1981: 54).

The tax regime of private charitable foundations, which allows the donor to take their tax deduction/credit at the time of donation, while the foundation spends this money on charity several years later, allows foundations not to be taxed on investment income, whereas if the founder had owned the property himself, he would have been taxed on said investment income (Halperin 2011: 307).

As for the capital gain that accumulates while the investment is held by the foundation, its effect on public finances depends on the type of asset donated. For example, in the case of shares of public companies, the fact that the foundation is non-taxable does not in itself represent an additional cost, because it is a capital gain exempt from tax for the donor at the time of donation. The impact on public finances is therefore already considered with the calculation of the loss of tax revenue at the time of the donation. For other assets, those that do not benefit from special tax treatment allowing exemption from tax at the time of donation, the capital gain exemption from income tax also represents an additional subsidy offered to the foundation.

In addition to these revenue losses for the public finances, the tax exemption granted to private charitable foundations can "create an unfair competitive advantage for philanthropic entities over for-profit businesses" (OECD Taxation and Philanthropy 2020).

\section{Conclusion}

To evaluate the treasury efficiency of the Canadian tax regime related to private foundations, it is therefore necessary to compare the revenue losses to the treasury resulting from the different incentives given to the founder (via the donation tax credit) and the foundation (via the tax holiday), with the present value the charity the foundation will be doing over the years. ${ }^{2}$ If the present value of the charity exceeds the revenue losses to the treasury, it generally means the regime represents a good deal for taxpayers.

However, if tax incentives related to private foundations and their founders are found to be treasury inefficient, it could still be a good initiative that benefits society. For example, the increased diversity that results from the fact that private foundations can provide services for which there is not enough demand to interest the state or the fact that private foundations, like other charities, allow taxpayers to use charitable donations and the tax benefits that flow from them as a means to vote on how public funds should be allocated (Levmore 1998: 411). 


\section{Are the tax incentives that private charitable foundations and their founders can benefit from in Canada treasury efficient?}

There are no official statistics relating to private charitable foundations and their founders in Canada. To evaluate the treasury efficiency of the tax regime related to private foundations in Canada, it is therefore necessary to make assumptions about the charity that private foundations really provide, the tax credits received by their founders on their donation and the value of the tax holiday for the foundation. To do this, official statistics on all donations in Canada and studies on private foundations published by non-governmental organisations will be studied. The structure of the tax system also allows reasonable assumptions to be made.

\subsection{Facts and assumptions}

Charity made by private foundations: Canada had 5,738 private foundations with assets totalling $\$ 56.3$ billion in 2018 . Their total wealth has increased by almost $200 \%$ since 2010 , from $\$ 19.4$ billion in 2010 to $\$ 56.3$ in 2018 .

The Income Tax Act requires private foundations to disburse at least 3.5\% of their total assets to charity annually. In June 2020, The Charity Report analysed the expenditures and charitable donations made by the 245 richest private foundations in Canada. According to this study, the combined assets of the top 245 private foundations in 2018 amounted to $\$ 42$ billion and they spent $3.34 \%$ of their assets on average, on expenditures and donations (The Charity Report 2020).

The assets and the charity (including the expenses related to charity) of the top 10 private foundations in Canada, excluding the MasterCard Foundation, is presented in Table 11.2. This calculation reflects the results from 2019, excluding the MasterCard Foundation, because it is a private corporate foundation subject to a different tax system from private foundations founded by individuals, and this chapter focuses on the latter. Table 11.2 shows that on average, these 10 foundations together spent on charity, in proportion to their assets, an average of $3.84 \%$ in 2019 , $3.69 \%$ in 2018 and $3.32 \%$ in 2017.

These findings are consistent with the study of Sansing and Yetman (2006), which concluded that private foundations respect the required disbursement quota to maintain their tax-exempt status, and when they exceed it, it is an immaterial amount above the minimum required (Sansing and Yetman 2006: 379).

Thus, to analyse the treasury efficiency, the disbursement quota of $3.5 \%$ required by the Canadian Income Tax Act will be used.

Donation tax credit: According to the Canadian tax system, donations that exceed $\$ 200$ attract a tax credit of $29 \%$, and if the individual has income in excess of $\$ 214,368$ (in 2020) and is therefore subject to the maximum tax rate of $33 \%$, he can benefit from a tax credit for donations calculated at the same rate of $33 \%$ on the excess of his donations over the threshold of $\$ 214,368$. Since 5,738 private foundations held $\$ 56.3$ billion in 2018 , or an average of $\$ 9.8$ million per foundation, founders of private foundations most probably benefit from the tax credit for donations that exceed $\$ 200$ and receive savings that vary between $29 \%$ and $33 \%$ at the federal level. Table 11.3, which presents official 2017 statistics on the federal donation tax credits, demonstrates that on average, Canadians received a tax credit equal to $29.3 \%$ of their donation, and Canadians with income exceeding $\$ 250,000$ received a tax credit of $32.5 \%$ of their donation. 
Table 11.2 Top 10 private (non-corporate) foundations in Canada - ratio charity/total assets (charity listing; Canada Revenue Agency)

\begin{tabular}{|c|c|c|c|c|c|c|}
\hline Foundation & Year & Total assets & Total & Charity & Adm. expenses & Charity/assets \\
\hline Fondation Lucie and & 2019 & $2,075,222,000$ & $86,012,000$ & $76,189,000$ & $9,823,000$ & $3.67 \%$ \\
\hline \multirow[t]{2}{*}{ André Chagnon } & 2018 & $1,955,782,000$ & $55,891,000$ & $46,863,000$ & $9,028,000$ & $2.40 \%$ \\
\hline & 2017 & $2,013,966,000$ & $55,207,000$ & $45,214,000$ & $9,993,000$ & $2.25 \%$ \\
\hline Li Ka Shing & 2019 & $1,039,417,449$ & $41,817,569$ & $39,280,789$ & $2,536,780$ & $3.78 \%$ \\
\hline (Canada) & 2018 & $867,319,784$ & $35,861,713$ & $34,282,695$ & $1,579,018$ & $3.95 \%$ \\
\hline Foundation & 2017 & $992,599,987$ & $38,039,589$ & $36,333,183$ & $1,706,406$ & $3.66 \%$ \\
\hline The J W McConnell & 2019 & $677,445,932$ & $31,259,226$ & $25,706,712$ & $5,552,514$ & $3.79 \%$ \\
\hline Family & 2018 & $628,873,297$ & $30,686,639$ & $26,021,051$ & $4,665,588$ & $4.14 \%$ \\
\hline Foundation & 2017 & $657,933,877$ & $29,956,008$ & $25,376,709$ & $4,579,299$ & $3.86 \%$ \\
\hline La Fondation & 2019 & $623,428,000$ & $24,484,753$ & $21,590,193$ & $2,894,560$ & $3.46 \%$ \\
\hline Marcelle-Jean & 2018 & $588,185,746$ & $24,517,331$ & $21,559,702$ & $2,957,629$ & $3.67 \%$ \\
\hline Coutu & 2017 & $583,182,186$ & $26,234,976$ & $23,488,495$ & $2,746,481$ & $4.03 \%$ \\
\hline The Rossy & 2019 & $728,975,044$ & $24,200,293$ & $23,729,335$ & 470,958 & $3.26 \%$ \\
\hline \multirow[t]{2}{*}{ Foundation } & 2018 & $537,487,120$ & $24,925,255$ & $24,587,899$ & 337,356 & $4.57 \%$ \\
\hline & 2017 & $834,902,674$ & $24,100,260$ & $23,792,295$ & 307,965 & $2.85 \%$ \\
\hline The Schulich & 2019 & $369,588,285$ & $16,362,594$ & $15,041,288$ & $1,321,306$ & $4.07 \%$ \\
\hline \multirow[t]{2}{*}{ Foundation } & 2018 & $367,377,905$ & $14,246,024$ & $13,075,690$ & $1,170,334$ & $3.56 \%$ \\
\hline & 2017 & $403,086,459$ & $13,901,815$ & $12,541,020$ & $1,360,795$ & $3.11 \%$ \\
\hline \multirow[t]{3}{*}{ Audain Foundation } & 2019 & $331,863,419$ & $5,119,178$ & $4,585,414$ & 533,764 & $1.38 \%$ \\
\hline & 2018 & $310,161,125$ & $7,533,075$ & $7,205,511$ & 327,564 & $2.32 \%$ \\
\hline & 2017 & $229,294,091$ & $8,571,226$ & $8,313,797$ & 257,429 & $3.63 \%$ \\
\hline \multirow{3}{*}{$\begin{array}{l}\text { The W. Garfield } \\
\text { Weston } \\
\text { Foundation }\end{array}$} & 2019 & $323,552,703$ & $36,562,977$ & $33,386,865$ & $3,176,112$ & $10.32 \%$ \\
\hline & 2018 & $296,149,220$ & $32,375,883$ & $29,356,340$ & $3,019,543$ & $9.91 \%$ \\
\hline & 2017 & $326,068,236$ & $28,581,360$ & $25,504,267$ & $3,077,093$ & $7.82 \%$ \\
\hline \multirow{3}{*}{$\begin{array}{l}\text { Fondation Mirella \& } \\
\quad \text { Lino Saputo }\end{array}$} & 2019 & $370,237,537$ & $10,770,080$ & $9,894,202$ & 875,878 & $2.67 \%$ \\
\hline & 2018 & $276,932,787$ & $10,033,340$ & $9,464,128$ & 569,212 & $3.42 \%$ \\
\hline & 2017 & $262,413,537$ & 7,930,029 & $7,347,132$ & 582,897 & $2.80 \%$ \\
\hline \multirow{6}{*}{$\begin{array}{l}\text { The Molson } \\
\text { Foundation }\end{array}$} & 2019 & $250,703,952$ & $11,276,713$ & $11,266,614$ & 10,099 & $4.49 \%$ \\
\hline & 2018 & $266,728,803$ & $12,749,308$ & $12,738,662$ & 10,646 & $4.78 \%$ \\
\hline & 2017 & $308,187,446$ & $11,635,435$ & $11,625,062$ & 10,373 & $3.77 \%$ \\
\hline & & & \multicolumn{3}{|c|}{ Ratio charity/total assets 2019} & $3.84 \%$ \\
\hline & & & \multicolumn{3}{|c|}{ Ratio charity/total assets 2018} & $3.69 \%$ \\
\hline & & & \multicolumn{3}{|c|}{ Ratio charity/total assets 2017} & $3.32 \%$ \\
\hline
\end{tabular}

The provinces also offer a tax credit on donations. The system is similar to that at the federal level, and the total tax credit on donations exceeding $\$ 200$, including federal and the provinces, varies between $40 \%$ in Ontario and 57\% in Quebec.

Value of the tax holiday for the foundation: The value of the tax holiday depends on the income earned by the foundation and the tax rate of the founder, because if these assets were not owned by the foundation, they would be owned and taxed at the founder's level.

Income earned by the foundation on its investment: The compounded annual gain in the S\&P 500 between 1965 and 2019 was 10\% (Berkshire Hathaway Inc. 2019). Even considering the COVID-19 crisis, the 2021 evaluation of the firm Vanguard is remarkably similar to last year's, and the outlook for global equities is $5 \%-7 \%$ over the next decade (Vanguard Economic and Market Outlook for 2021: Approaching the Dawn: 35). The rates on return earned by the 
Table 11.3 Donation tax credit in Canada - Statistics 2017

CRA, Statistics on T1, edition 2019 (taxation year 2017)

\begin{tabular}{lrr}
\hline & Total & $\begin{array}{l}\text { Income } \\
>250,000\end{array}$ \\
\hline Donation & & 199,000 \\
- Number of taxpayers & $5,529,010$ & $\$ 3,487,992$ \\
- In thousands of CND\$ & $\$ 10,491,945$ & \\
Tax credits & $\$ 3,076,860$ & $\$ 1,135,395(37 \%)$ \\
- In thousands of CND\$ & & \\
\hline
\end{tabular}

Table 11.4 Tax rates for capital gains, dividends and interest incomes

For taxpayers in higher tax brackets established in Ontario and Quebec

\begin{tabular}{llll}
\hline & \multicolumn{2}{l}{ Income of $>\$ 244,800$} & \\
\cline { 2 - 4 } & Interest & Dividends & Capital gains \\
\hline Quebec & $53,53 \%$ & $40,11 \%$ & $26,65 \%$ \\
Ontario & $53,31 \%$ & $39,34 \%$ & $26,76 \%$ \\
\hline
\end{tabular}

top three richest private foundations in Canada during the years 2017-2018-2019 were 6\% for the Fondation Lucie et André Chagnon, 3\% for the Li Ka Shing (Canada) foundation and 7\% for the Fondation Marcelle-Jean Coutu (Charity Listing, CRA). Thus, for the purposes of this analysis, a rate of return of $5 \%$ will be used, because it seems to be the most conservative rate, considering these different facts and expectations.

Tax rate of the founder: As explained previously, since private charitable foundations in Canada hold, on average, assets totalling $\$ 9.8$ million, it makes sense to conclude that it is the wealthiest people who have the resources to set up such a structure, as well as to assume that these foundations are generally founded by individuals in the top $1 \%$ of earners in Canada. This represents a group of 283,015 individuals earning more than $\$ 244,800$ per year in 2018 (Statistics Canada, High Income Filers in Canada 2020).

Furthermore, Table 11.3 indicates that in $2017,37 \%$ of total tax credits benefited taxpayers with an income exceeding $\$ 250,000$. While this is not a direct correlation with the founders of private charitable foundations, these statistics confirm that donations in Canada come largely from the top $1 \%$.

In Canada, as in many jurisdictions, investment incomes are taxed differently depending on the nature of the income. Table 11.4 presents the tax rates on interest incomes, dividends and capital gains for the top 1\% of earners in Ontario and Quebec, the most popular provinces for private foundations. It is not possible with the available data to calculate the exact tax rates, but for the purpose of this chapter, an average tax rate of $40 \%$ seems conservative and probable and will be used in the present analysis.

\subsection{Treasury efficiency evaluation}

As presented in Section 2, the analysis of treasury efficiency requires a comparison to be made of the present-day value of the charity that the foundation provides over time and the present 
value of the tax holiday from which it benefits, as well as the tax credit enjoyed by the founder at the time of the creation of the foundation.

To bring money back to today's value, the right discount rate needs to be determined. To think about the right rate, it is necessary to place yourself in the position of the Canadian government, since it is the one that has to take the final decision to grant the funds.

As in many countries, Canada must borrow presently to face the crisis, and the situation will stay the same in years to come. Total Canadian government borrowing was $\$ 1.421$ trillion as of October 31, 2020, and an additional $\$ 323$ billion in borrowing is expected through 2024 . The needs are dire for health, education and social services, and if Canada gives tax incentives to the founders and their private foundations, who for the most part also have goals related to health, education and social services but who withhold these sums from a long-term perspective, the country faces a shortfall that it needs now and urgently. So, the current decision to invest in private charitable foundations results in more borrowing for Canada, and the cost of postponing health, education and social services into the future through private charitable foundations corresponds to the cost of its debt.

The average effective interest rate on the government's interest-bearing debt in 2019 was $2.3 \%$, up from $2.2 \%$ in 2018 , and the average effective interest rate in 2020 remained at $2.3 \%$ (Government of Canada-Public Accounts of Canada 2020). Although it is not certain what will happen to interest rates within the next few months and years, an interest rate of $2.3 \%$ seems to reflect the current tendency. Annexes 1-2-3 present an analysis of the treasury efficiency of the tax incentives that private charitable foundations and their founders may benefit from in Canada on a donation of $\$ 100$ million, considering the different facts and assumptions presented previously and a discount rate of $2.3 \%$.

Annexes 1 and 2 evaluate the treasury analysis of the tax regime over a period of 38 years and 53 years, respectively. Annex 1 demonstrates that it takes 38 years for the foundation to give back to society sufficient charity to balance the tax incentives the foundation and its founder receive at a rate of $44 \%$. Annex 2 demonstrates that it takes 53 years for the foundation to give back to society sufficient charity to balance the tax incentives the foundation and its founder receive at a rate of $57 \%$.

Annex 3 demonstrates that the disbursement quota would need to be increased to $5.5 \%$ if we want to reach treasury efficiency within a period of 20 years.

\section{Conclusion}

This chapter does not question the relevance and charitable nature of foundations or donors. Several qualified people have already spoken on this issue. For example, in 2006, Pope Benedict XVI clarified in his book Deus caritas est, or God Is Love, that charity is essential and that there is no substitute for charity, not even the state.

As private charitable foundations have become an important social pillar, it is important to ensure that tax regimes are an effective tool to put private foundations truly at the service of the state and its citizens. As demonstrated in this chapter, the current tax system in Canada is not treasury efficient, unless it is considered that 38 to 53 years is a reasonable time to balance the coffers of the state, which is obviously not the case, especially in times of crisis.

The last major tax reform of the Canadian tax system related to private foundations dates back almost 50 years, and the time may have come to rethink the subject in depth. 


\section{Notes}

1 This concluding statement is presented in the report On Time, Value, E Philanthropy that followed the informal discussion that took place at the Atlantic Philanthropies on 10 May 2016. Available at: https:// cspcs.sanford.duke.edu/sites/default/files/March\%2010\%20Time-Value\%20Meeting\%20Recap\%20 5-13-16.pdf

2 Other considerations can be factored into the efficiency evaluation. The economies of scale that the state benefits from are a good example because, generally, private foundations cannot count on these reduced costs, and, to be exact, these costs should be accounted in the efficiency analysis (Parachin 2013: 39).

\section{Bibliography}

Afik, Z. and Katz, H., 2018. Reconsidering the philanthropic foundation minimum payout policy under a "new normal". Journal of Policy Modeling. Available at: https://doi.org/10.1016/j.jpolmod.2018.09.004.

Alberg-Seberich, M., 2018. Analyzing Canada's philanthropy support landscape to enhance giving. The Philanthropist, European Philanthropy [online]. Available at: http://file:///Users/gabriellasobodker/Downloads/analyzing-canadas-philanthropy-support-landscape-to-enhance-giving\%20(1).pdf [Accessed 31 January 2021].

Backus, P. and Grant, N., 2019. How sensitive is the average taxpayer to changes in the tax-price of giving? International Tax and Public Finance, vol. 26/2, pp. 317-356.

Banque du Canada; Ministère des Finances du Canada, Tableaux de référence financiers - 2018, Tableau 13. Available at: https://www.canada.ca/fr/ministere-finances/services/publications/tableaux-referencefinanciers/2019/partie-3.html\#tbl13 [Accessed 31 January 2021].

Benshalom, Ilan, 2009. The dual subsidy theory of charitable deductions. Indiana Law Journal, vol. 84/4, Article 1.

Berkshire Hathaway Inc., 2020. Berkshire's Performance vs. the SEP 500 [online]. Available at: https://www. berkshirehathaway.com/letters/2019ltr.pdf [Accessed 31 January 2021].

Bourgeois, Donald, 2010. Eliminating the disbursement quota: Gold or fool's gold? The Philanthropist, vol. 23/2, pp. 184-189.

Brody, Evelyn, 1997. Charitable endowments and the democratization of dynasty. Arizona Law Review, vol. 39, p. 873 [online]. Available at: https://scholarship.kentlaw.iit.edu/fac_schol/115 [Accessed 31 January 2021].

Brody, Evelyn. 1999. Charities in tax reform: Threats to subsidies overt and covert. Tennessee Law Review, vol. 66, p. 687 [online]. Available at: http://scholarship.kentlaw.iit.edu/fac_schol/116.

Canada Revenue Agency, T1 Final Statistics 2019 Edition (for the 2017 Tax Year) [online]. Available at: https://www.canada.ca/en/revenue-agency/programs/about-canada-revenue-agency-cra/incomestatistics-gst-hst-statistics/t1-final-statistics/2017-tax-year.html.

Clotfelter, C., 1985. Federal Tax Policy and Charitable Giving. Chicago: University of Chicago Press.

Colinvaux, R., 2016. Using tax law to discourage donor-imposed restrictions on charitable gifts. Ncpl.law. nүu.edu [online]. Available at: https://ncpl.law.nyu.edu/wp-content/uploads/2017/03/Tab-E-Colinvaux-paper.pdf [Accessed 24 January 2021].

Department of Finance Canada, Report on Federal Tax Expenditures 2019 [online]. Available at: https://www. canada.ca/en/department-finance/services/publications/federal-tax-expenditures/2020/part-1.html.

Department of Finance Canada, Debt Management Report 2018-2019 [online]. Available at: https://www. canada.ca/en/department-finance/services/publications/debt-management-report/2018-2019.html

Donation States, 2016. An international comparison of the tax treatment of donations. Charities Aid Foundation [online]. Available at: https://www.cafonline.org/docs/default-source/about-us-publications/ fwg4-donation-states [Accessed 31 January 2021].

Efc.issuelab.org., 2015. Comparative Highlights of Foundation Laws: The Operating Environment for Foundations in Europe 2015 [online]. Available at: https://efc.issuelab.org/resource/comparative-highlightsof-foundation-laws-the-operating-environment-for-foundations-in-europe-2015.html [Accessed 31 January 2021].

Elson, P. R., 2007a. A short history of voluntary sector-government relations in Canada. Thephilanthropist.ca [online]. Available at: https://thephilanthropist.ca/original-pdfs/Philanthropist-21-1-358.pdf [Accessed 31 January 2021]. 
Elson, P. R., 2007b. High Ideals and Noble Intentions: Voluntary Sector-Government Relations in Canada. Toronto: University of Toronto Press.

Elson, P. R., 2010. The origin of the species: Why charity regulations in Canada and England continue to reflect their origins. The International Journal of Non-for-Profit Law, vol. 12/3, disponible en ligne.

Elson, P. R., Lefevre, S. and Fontan, J., 2020. Philanthropic Foundations in Canada, Landscapes, Indigenous Perspectives and Pathways to Change [online]. Available at: https://philab.uqam.ca/en/publication/ philanthropic-foundations-in-canada-landscapes-indigenous-perspectives-and-pathways-to-change/.

Fack, G. and Landais, C. 2010. Are tax incentives for charitable giving efficient? Evidence from France. American Economic Journal: Economic Policy, vol. 2/2, pp. 117-141.

Feld, Joel H., 1967. Unreasonable accumulation of income by foundations. Cleveland State Law Review, vol. 16, p. 362.

Feldstein, M., 1975. The income tax and charitable contributions: Part I - aggregate and distributional effect. National Tax Journal, vol. 28/1.

Fondationdefrance.org., 2015. An Overview of Philanthropy in Europe [online]. Available at: https://www. fondationdefrance.org/sites/default/files/atoms/files/philanthropy_in_europe_2015.pdf [Accessed 31 January 2021].

Fontan, J., Elson, P. and Lefevre, S., 2017. Les fondations philanthropiques: de nouveaux acteurs politiques?. Quebec: Presses de l'Université du Québec.

Galle, Brian, 2016. Pay it forward? Law and the problem of restricted-spending philanthropy. Washington University Law Review, vol. 1143.

Government of Canada, 2020. Public Accounts of Canada [online]. Available at: https://www.tpsgc-pwgsc. gc.ca/recgen/cpc-pac/2019/vol1/s1/aef-fsda-eng.html [Accessed 31 January 2021].

Granatstein, J. and Kucharsky, D., 2008. Vincent Massey | The Canadian encyclopedia. Thecanadianencyclopedia.ca [online]. Available at: https://www.thecanadianencyclopedia.ca/en/article/massey-charlesvincent [Accessed 31 January 2021].

Halperin, Daniel I., 2002. A charitable contribution of appreciated property and the realization of built-in gains. Tax Law Review, vol. 56/1.

Halperin, Daniel I., 2011. Is income tax exemption for charities a subsidy?. Tax Law Review, vol. 64, p. 283, 15 July [online]. Available at: https://ssrn.com/abstract=1920430.

Hansmann, Henry, 1981 The rationale for exempting nonprofit organizations from the corporate income taxation. Yale Law Journal, vol. 98 [online]. Available at: https://digitalcommons.law.yale.edu/ylj/ vol91/iss1/3 [Accessed 31 January 2021].

Income Tax Act, par. 149.1(1) ‘qualified donees' ITA and s. 985.1b) Taxation Act.

Income Tax Act, RSC 1985, c. 1 (5th Supp.), as amended.

Jansen, P. J. and Katz, D. M., 2002. For Nonprofits, Time Is Money. Atlanta, GA: McKinsey \& Co.

Klausner, Michael D., 2003. When Time Isn't Money: Foundation Payouts and the Time Value of Money. Available at SSRN: https://ssrn.com/abstract=445982 or http://dx.doi.org/10.2139/ssrn.445982

Levmore, S., 1998. Taxes as ballots. University of Chicago Law Review, vol. 65/2, pp. 387-432.

OECD, 2018. Private Philanthropy for Development, The Development Dimension. Paris: OECD Publishing.

OECD, 2020. La fiscalité et la philanthropie. Études de politique fiscale de l'OCDE, No. 27. Paris: OECD Publishing.

Parachin, A., 2013. The charitable contributions deduction, a tax debate or a question of charity versus government? Urban.org. [online]. Available at: https://www.urban.org/sites/default/files/ publication/23616/412818-The-Charitable-Contributions-Deduction-A-Tax-Debate-or-a-Question-of-Charity-Versus-Government-.PDF [Accessed 24 January 2021].

Peloza, John and Steel, Piers, 2005. The price elasticities of charitable contributions: A meta-analysis. Journal of Public Policy \& Marketing, vol. 24, pp. 260-272.

Pfc.ca., 2021. A Portrait of Canadian Foundation Philanthropy: Canada National Report for the Global Philanthropy Project at Harvard Kennedy School. Montreal: Philanthropic Foundations Canada [online]. Available at: http://pfc.ca/wp-content/uploads/2018/01/portrait-cdn-philanthropy-sept2017-en.pdf [Accessed 31 January 2021].

Philanthropic Foundations Canada, 2019. Starting a Foundation, a Guide for Philanthropists. Philanthropic Foundations Canada [online]. Available at: http://pfc.ca/wp-content/uploads/2019/06/starting_foundation_2019_en.pdf [Accessed 31 January 2021].

Philanthropic Foundations Canada, 2021. Canadian Foundation Facts.

Pope Benedict XVI. 2006, "God Is Love” [Deus Caritas Est]. 
Porter, Michael E. and Kramer, Mark R., 1999. Philanthropy's new agenda: Creating value. Harvard Business Review, vol. 77/6, pp. 121-122, November-December.

Randolph, W., 1995. Dynamic income, progressive taxes, and the timing of charitable contributions. Journal of Political Economy, vol. 91/1, pp. 703-738.

Roger, Colinvaux, 2013. Charitable contributions of property: A broken system reimagined. Harvard Journal on Legislation, vol. 50, p. 263.

Sansing, Richard and Yetman, Robert, 2006. Governing private foundations using the tax law. Journal of Accounting and Economics, vol. 41, pp. 363-384. doi:10.1016/j.jacceco.2005.03.003.

Sectorsource.ca., 2014. Sector Impact: What Is the Charitable and Nonprofit Sector? [online]. Available at: http://sectorsource.ca/research-and-impact/sector-impact [Accessed 31 January 2021].

Simon, J., 1987. The tax treatment of nonprofit organizations: A review of federal and state policies. In W. W. Powell (Ed.), The Nonprofit Sector: A Research Handbook (pp. 67-98). New Haven, CT: Yale University Press.

Simon, J., 1995. The regulation of American foundations: Looking backward at the tax reform act of 1969. Voluntas: International Journal of Voluntary and Nonprofit Organizations, vol. 6/3, pp. 243-254 [online]. Available at: http://www.jstor.org/stable/27927481 [Accessed 25 January 2021].

Statistics Canada, 2020. Statistics Canada, High Income Tax Filers in Canada (Year 2018). Available at: https:// www150.statcan.gc.ca/t1/tbl1/en/tv.action?pid=1110005501 [Accessed 1 February 2021].

Statistics Canada, Table 11-10-0130-01 Summary of Charitable Donors [online]. Available at: https:// www150.statcan.gc.ca/t1/tbl1/en/tv.action?pid=1110013001 [Accessed 31 January 2021].

Taxation Act, CQLR, c. I-3, s. 752.0.10.1 to 752.0.10.18.

The Charity Report, 2020. Who Gives and Who Gets: The Beneficiaries of Private Foundation Philanthropy.

Toepler, S., 2004. Ending payout as we know it: A conceptual and comparative perspective on the payout requirement for foundations. Nonprofit and Voluntary Sector Quarterly, vol. 33/4, pp. 729-738.

Treasury Department Report on Private Foundations, Comm. Print., Comm. On Finance, U. S. Senate 89th Cong., 1st Sess. 55, 2 February 1965.

Treasury Department Report on Private Foundations, 1966. Real Property, Probate and Trust Journal, vol. 1/3, pp. 292-306 [online]. Available at: http://www.jstor.org/stable/20780665 [Accessed 26 January 2021].

Weisbach, David A. and Sunstein, Cass R., 2009. Climate change and discounting the future: A guide for the perplexed. Yale Law and Policy Review, vol. 27, pp. 433-457.

Vanguard Research, 2020. Vanguard economic and market outlook for 2021: Approaching the dawn. Vanguard [online]. Available at: <https://pressroom.vanguard.com/nonindexed/Vanguard-economicand-market-outlook-report-2021-120920.pdf> [Accessed 31 January 2021]. 


\section{ANNEX 11.1 - TREASURY EFFICIENCY - ANALYSIS ON 38 YEARS}

\begin{tabular}{|c|c|c|c|c|c|c|c|}
\hline Year & $\begin{array}{l}\text { Cost of tax } \\
\text { credit for the } \\
\text { public finances } \\
(44 \%)\end{array}$ & $\begin{array}{l}\text { Cost of tax } \\
\text { credit for the } \\
\text { public finances } \\
(57 \%)\end{array}$ & $\begin{array}{l}\text { Cost of the } \\
\text { tax holiday } \\
\text { for the public } \\
\text { finances }\end{array}$ & $\begin{array}{l}\text { Distribution } \\
\text { (charity) }\end{array}$ & $\begin{array}{l}\text { Net benefit: } \\
\text { distribution } \\
\text { less the cost } \\
\text { of the tax } \\
\text { holiday }\end{array}$ & $\begin{array}{l}\text { Net benefit: } \\
\text { current value } \\
\text { over } 25 \text { years }\end{array}$ & $\begin{array}{l}\text { Balance of } \\
\text { capital in the } \\
\text { foundation, } \\
\text { after } \\
\text { distribution } \\
\text { and expenses }\end{array}$ \\
\hline & $44,000,000$ & $57,000,000$ & & & & $44,412,781$ & \\
\hline 1 & & & $2,000,000$ & $3,500,000$ & $1,500,000$ & $1,466,276$ & $101,000,000$ \\
\hline 2 & & & $2,020,000$ & $3,535,000$ & $1,515,000$ & $1,447,643$ & $102,010,000$ \\
\hline 3 & & & $2,040,200$ & $3,570,350$ & $1,530,150$ & $1,429,246$ & $103,030,100$ \\
\hline 4 & & & $2,060,602$ & $3,606,054$ & $1,545,452$ & $1,411,084$ & $104,060,401$ \\
\hline 5 & & & $2,081,208$ & $3,642,114$ & $1,560,906$ & $1,393,152$ & $105,101,005$ \\
\hline 6 & & & $2,102,020$ & $3,678,535$ & $1,576,515$ & $1,375,448$ & $106,152,015$ \\
\hline 7 & & & $2,123,040$ & $3,715,321$ & $1,592,280$ & $1,357,970$ & $107,213,535$ \\
\hline 8 & & & $2,144,271$ & $3,752,474$ & $1,608,203$ & $1,340,713$ & $108,285,671$ \\
\hline 9 & & & $2,165,713$ & $3,789,998$ & $1,624,285$ & $1,323,676$ & $109,368,527$ \\
\hline 10 & & & $2,187,371$ & $3,827,898$ & $1,640,528$ & $1,306,855$ & $110,462,213$ \\
\hline 11 & & & $2,209,244$ & $3,866,177$ & $1,656,933$ & $1,290,247$ & $111,566,835$ \\
\hline 12 & & & $2,231,337$ & $3,904,839$ & $1,673,503$ & $1,273,851$ & $112,682,503$ \\
\hline 13 & & & $2,253,650$ & $3,943,888$ & $1,690,238$ & $1,257,664$ & $113,809,328$ \\
\hline 14 & & & $2,276,187$ & $3,983,326$ & $1,707,140$ & $1,241,682$ & $114,947,421$ \\
\hline 15 & & & $2,298,948$ & $4,023,160$ & $1,724,211$ & $1,225,903$ & $116,096,896$ \\
\hline 16 & & & $2,321,938$ & $4,063,391$ & $1,741,453$ & $1,210,324$ & $117,257,864$ \\
\hline 17 & & & $2,345,157$ & $4,104,025$ & $1,758,868$ & $1,194,944$ & $118,430,443$ \\
\hline 18 & & & $2,368,609$ & $4,145,066$ & $1,776,457$ & $1,179,759$ & $119,614,748$ \\
\hline 19 & & & $2,392,295$ & $4,186,516$ & $1,794,221$ & $1,164,767$ & $120,810,895$ \\
\hline 20 & & & $2,416,218$ & $4,228,381$ & $1,812,163$ & $1,149,965$ & $122,019,004$ \\
\hline 21 & & & $2,440,380$ & $4,270,665$ & $1,830,285$ & $1,135,352$ & $123,239,194$ \\
\hline 22 & & & $2,464,784$ & $4,313,372$ & $1,848,588$ & $1,120,924$ & $124,471,586$ \\
\hline 23 & & & $2,489,432$ & $4,356,506$ & $1,867,074$ & $1,106,680$ & $125,716,302$ \\
\hline 24 & & & $2,514,326$ & $4,400,071$ & $1,885,745$ & $1,092,616$ & $126,973,465$ \\
\hline
\end{tabular}


Treasury efficiency of Canadian tax

\begin{tabular}{|c|c|c|c|c|c|c|c|}
\hline Year & $\begin{array}{l}\text { Cost of tax } \\
\text { credit for the } \\
\text { public finances } \\
(44 \%)\end{array}$ & $\begin{array}{l}\text { Cost of tax } \\
\text { credit for the } \\
\text { public finances } \\
(57 \%)\end{array}$ & $\begin{array}{l}\text { Cost of the } \\
\text { tax holiday } \\
\text { for the public } \\
\text { finances }\end{array}$ & $\begin{array}{l}\text { Distribution } \\
\text { (charity) }\end{array}$ & $\begin{array}{l}\text { Net benefit: } \\
\text { distribution } \\
\text { less the cost } \\
\text { of the tax } \\
\text { holiday }\end{array}$ & $\begin{array}{l}\text { Net benefit: } \\
\text { current value } \\
\text { over } 25 \text { years }\end{array}$ & $\begin{array}{l}\text { Balance of } \\
\text { capital in the } \\
\text { foundation, } \\
\text { after } \\
\text { distribution } \\
\text { and expenses }\end{array}$ \\
\hline 25 & & & $2,539,469$ & $4,444,071$ & $1,904,602$ & $1,078,732$ & $128,243,200$ \\
\hline 26 & & & $2,564,864$ & $4,488,512$ & $1,923,648$ & $1,065,023$ & $129,525,631$ \\
\hline 27 & & & $2,590,513$ & $4,533,397$ & $1,942,884$ & $1,051,489$ & $130,820,888$ \\
\hline 28 & & & $2,616,418$ & $4,578,731$ & $1,962,313$ & $1,038,127$ & $132,129,097$ \\
\hline 29 & & & $2,642,582$ & $4,624,518$ & $1,981,936$ & $1,024,935$ & $133,450,388$ \\
\hline 30 & & & $2,669,008$ & $4,670,764$ & $2,001,756$ & $1,011,910$ & $134,784,892$ \\
\hline 31 & & & $2,695,698$ & $4,717,471$ & $2,021,773$ & 999,051 & $136,132,740$ \\
\hline 32 & & & $2,722,655$ & $4,764,646$ & $2,041,991$ & 986,356 & $137,494,068$ \\
\hline 33 & & & $2,749,881$ & $4,812,292$ & $2,062,411$ & 973,821 & $138,869,009$ \\
\hline 34 & & & $2,777,380$ & $4,860,415$ & $2,083,035$ & 961,446 & $140,257,699$ \\
\hline 35 & & & $2,805,154$ & $4,909,019$ & $2,103,865$ & 949,229 & $141,660,276$ \\
\hline 36 & & & $2,833,206$ & $4,958,110$ & $2,124,904$ & 937,166 & $143,076,878$ \\
\hline 37 & & & $2,861,538$ & $5,007,691$ & $2,146,153$ & 925,257 & $144,507,647$ \\
\hline 38 & & & $2,890,153$ & $5,057,768$ & $2,167,615$ & 913,499 & $145,952,724$ \\
\hline
\end{tabular}




\section{ANNEX 11.2 - TREASURY EFFICIENCY - ANALYSIS ON 53 YEARS}

\begin{tabular}{|c|c|c|c|c|c|c|c|}
\hline Year & $\begin{array}{l}\text { Cost of tax } \\
\text { credit for the } \\
\text { public finances } \\
(44 \%)\end{array}$ & $\begin{array}{l}\text { Cost of tax } \\
\text { credit for the } \\
\text { public finances } \\
(57 \%)\end{array}$ & $\begin{array}{l}\text { Cost of the } \\
\text { tax holiday } \\
\text { for the public } \\
\text { finances }\end{array}$ & $\begin{array}{l}\text { Distribution } \\
\text { (charity) }\end{array}$ & $\begin{array}{l}\text { Net benefit: } \\
\text { distribution } \\
\text { less the cost } \\
\text { of the tax } \\
\text { holiday }\end{array}$ & $\begin{array}{l}\text { Net benefit: } \\
\text { current value } \\
\text { over } 25 \text { years }\end{array}$ & $\begin{array}{l}\text { Balance of } \\
\text { capital in the } \\
\text { foundation, } \\
\text { after } \\
\text { distribution } \\
\text { and expenses }\end{array}$ \\
\hline & $44,000,000$ & $57,000,000$ & & & & $56,801,545$ & \\
\hline 1 & & & $2,000,000$ & $3,500,000$ & $1,500,000$ & $1,466,276$ & $101,000,000$ \\
\hline 2 & & & $2,020,000$ & $3,535,000$ & $1,515,000$ & $1,447,643$ & $102,010,000$ \\
\hline 3 & & & $2,040,200$ & $3,570,350$ & $1,530,150$ & $1,429,246$ & $103,030,100$ \\
\hline 4 & & & $2,060,602$ & $3,606,054$ & $1,545,452$ & $1,411,084$ & $104,060,401$ \\
\hline 5 & & & $2,081,208$ & $3,642,114$ & $1,560,906$ & $1,393,152$ & $105,101,005$ \\
\hline 6 & & & $2,102,020$ & $3,678,535$ & $1,576,515$ & $1,375,448$ & $106,152,015$ \\
\hline 7 & & & $2,123,040$ & $3,715,321$ & $1,592,280$ & $1,357,970$ & $107,213,535$ \\
\hline 8 & & & $2,144,271$ & $3,752,474$ & $1,608,203$ & $1,340,713$ & $108,285,671$ \\
\hline 9 & & & $2,165,713$ & $3,789,998$ & $1,624,285$ & $1,323,676$ & $109,368,527$ \\
\hline 10 & & & $2,187,371$ & $3,827,898$ & $1,640,528$ & $1,306,855$ & $110,462,213$ \\
\hline 11 & & & $2,209,244$ & $3,866,177$ & $1,656,933$ & $1,290,247$ & $111,566,835$ \\
\hline 12 & & & $2,231,337$ & $3,904,839$ & $1,673,503$ & $1,273,851$ & $112,682,503$ \\
\hline 13 & & & $2,253,650$ & $3,943,888$ & $1,690,238$ & $1,257,664$ & $113,809,328$ \\
\hline 14 & & & $2,276,187$ & $3,983,326$ & $1,707,140$ & $1,241,682$ & $114,947,421$ \\
\hline 15 & & & $2,298,948$ & $4,023,160$ & $1,724,211$ & $1,225,903$ & $116,096,896$ \\
\hline 16 & & & $2,321,938$ & $4,063,391$ & $1,741,453$ & $1,210,324$ & $117,257,864$ \\
\hline 17 & & & $2,345,157$ & $4,104,025$ & $1,758,868$ & $1,194,944$ & $118,430,443$ \\
\hline 18 & & & $2,368,609$ & $4,145,066$ & $1,776,457$ & $1,179,759$ & $119,614,748$ \\
\hline 19 & & & $2,392,295$ & $4,186,516$ & $1,794,221$ & $1,164,767$ & $120,810,895$ \\
\hline 20 & & & $2,416,218$ & $4,228,381$ & $1,812,163$ & $1,149,965$ & $122,019,004$ \\
\hline 21 & & & $2,440,380$ & $4,270,665$ & $1,830,285$ & $1,135,352$ & $123,239,194$ \\
\hline 22 & & & $2,464,784$ & $4,313,372$ & $1,848,588$ & $1,120,924$ & $124,471,586$ \\
\hline 23 & & & $2,489,432$ & $4,356,506$ & $1,867,074$ & $1,106,680$ & $125,716,302$ \\
\hline 24 & & & $2,514,326$ & $4,400,071$ & $1,885,745$ & $1,092,616$ & $126,973,465$ \\
\hline
\end{tabular}


Treasury efficiency of Canadian tax

\begin{tabular}{|c|c|c|c|c|c|c|c|}
\hline Year & $\begin{array}{l}\text { Cost of tax } \\
\text { credit for the } \\
\text { public finances } \\
(44 \%)\end{array}$ & $\begin{array}{l}\text { Cost of tax } \\
\text { credit for the } \\
\text { public finances } \\
(57 \%)\end{array}$ & $\begin{array}{l}\text { Cost of the } \\
\text { tax holiday } \\
\text { for the public } \\
\text { finances }\end{array}$ & $\begin{array}{l}\text { Distribution } \\
\text { (charity) }\end{array}$ & $\begin{array}{l}\text { Net benefit: } \\
\text { distribution } \\
\text { less the cost } \\
\text { of the tax } \\
\text { holiday }\end{array}$ & $\begin{array}{l}\text { Net benefit: } \\
\text { current value } \\
\text { over } 25 \text { years }\end{array}$ & $\begin{array}{l}\text { Balance of } \\
\text { capital in the } \\
\text { foundation, } \\
\text { after } \\
\text { distribution } \\
\text { and expenses }\end{array}$ \\
\hline 25 & & & $2,539,469$ & $4,444,071$ & $1,904,602$ & $1,078,732$ & $128,243,200$ \\
\hline 26 & & & $2,564,864$ & $4,488,512$ & $1,923,648$ & $1,065,023$ & $129,525,631$ \\
\hline 27 & & & $2,590,513$ & $4,533,397$ & $1,942,884$ & $1,051,489$ & $130,820,888$ \\
\hline 28 & & & $2,616,418$ & $4,578,731$ & $1,962,313$ & $1,038,127$ & $132,129,097$ \\
\hline 29 & & & $2,642,582$ & $4,624,518$ & $1,981,936$ & $1,024,935$ & $133,450,388$ \\
\hline 30 & & & $2,669,008$ & $4,670,764$ & $2,001,756$ & $1,011,910$ & $134,784,892$ \\
\hline 31 & & & $2,695,698$ & $4,717,471$ & $2,021,773$ & 999,051 & $136,132,740$ \\
\hline 32 & & & $2,722,655$ & $4,764,646$ & $2,041,991$ & 986,356 & $137,494,068$ \\
\hline 33 & & & $2,749,881$ & $4,812,292$ & $2,062,411$ & 973,821 & $138,869,009$ \\
\hline 34 & & & $2,777,380$ & $4,860,415$ & $2,083,035$ & 961,446 & $140,257,699$ \\
\hline 35 & & & $2,805,154$ & $4,909,019$ & $2,103,865$ & 949,229 & $141,660,276$ \\
\hline 36 & & & $2,833,206$ & $4,958,110$ & $2,124,904$ & 937,166 & $143,076,878$ \\
\hline 37 & & & $2,861,538$ & $5,007,691$ & $2,146,153$ & 925,257 & $144,507,647$ \\
\hline 38 & & & $2,890,153$ & $5,057,768$ & $2,167,615$ & 913,499 & $145,952,724$ \\
\hline 39 & & & $2,919,054$ & $5,108,345$ & $2,189,291$ & 901,890 & $147,412,251$ \\
\hline 40 & & & $2,948,245$ & $5,159,429$ & $2,211,184$ & 890,429 & $148,886,373$ \\
\hline 41 & & & $2,977,727$ & $5,211,023$ & $2,233,296$ & 879,114 & $150,375,237$ \\
\hline 42 & & & $3,007,505$ & $5,263,133$ & $2,255,629$ & 867,943 & $151,878,989$ \\
\hline 43 & & & $3,037,580$ & $5,315,765$ & $2,278,185$ & 856,913 & $153,397,779$ \\
\hline 44 & & & $3,067,956$ & $5,368,922$ & $2,300,967$ & 846,024 & $154,931,757$ \\
\hline 45 & & & $3,098,635$ & $5,422,612$ & $2,323,976$ & 835,273 & $156,481,075$ \\
\hline 46 & & & $3,129,621$ & $5,476,838$ & $2,347,216$ & 824,658 & $158,045,885$ \\
\hline 47 & & & $3,160,918$ & $5,531,606$ & $2,370,688$ & 814,179 & $159,626,344$ \\
\hline 48 & & & $3,192,527$ & $5,586,922$ & $2,394,395$ & 803,832 & $161,222,608$ \\
\hline 49 & & & $3,224,452$ & $5,642,791$ & $2,418,339$ & 793,617 & $162,834,834$ \\
\hline 50 & & & $3,256,697$ & $5,699,219$ & $2,442,523$ & 783,532 & $164,463,182$ \\
\hline 51 & & & $3,289,264$ & $5,756,211$ & $2,466,948$ & 773,575 & $166,107,814$ \\
\hline 52 & & & $3,322,156$ & $5,813,773$ & $2,491,617$ & 763,745 & $167,768,892$ \\
\hline 53 & & & $3,355,378$ & $5,871,911$ & $2,516,533$ & 754,040 & $169,446,581$ \\
\hline
\end{tabular}




\section{ANNEX 11.3 - TREASURY EFFICIENCY - ANALYSIS ON 20 YEARS, DISBURSEMENT QUOTA OF 5.5\%}

\begin{tabular}{|c|c|c|c|c|c|c|c|}
\hline Year & $\begin{array}{l}\text { Cost of tax } \\
\text { credit for the } \\
\text { public finances } \\
(44 \%)\end{array}$ & $\begin{array}{l}\text { Cost of tax } \\
\text { credit for the } \\
\text { public finances } \\
(57 \%)\end{array}$ & $\begin{array}{l}\text { Cost of the } \\
\text { tax holiday } \\
\text { for the public } \\
\text { finances }\end{array}$ & $\begin{array}{l}\text { Distribution } \\
\text { (charity) }\end{array}$ & $\begin{array}{l}\text { Net benefit: } \\
\text { distribution } \\
\text { less the cost } \\
\text { of the tax } \\
\text { holiday }\end{array}$ & $\begin{array}{l}\text { Net benefit: } \\
\text { current value } \\
\text { over } 25 \text { years }\end{array}$ & $\begin{array}{l}\text { Balance of } \\
\text { capital in the } \\
\text { foundation, } \\
\text { after } \\
\text { distribution } \\
\text { and expenses }\end{array}$ \\
\hline & $44,000,000$ & $57,000,000$ & & & & $51,012,127$ & \\
\hline 1 & & & $2,000,000$ & $5,500,000$ & $3,500,000$ & $3,421,310$ & $99,000,000$ \\
\hline 2 & & & $1,980,000$ & $5,445,000$ & $3,465,000$ & $3,310,945$ & $98,010,000$ \\
\hline 3 & & & $1,960,200$ & $5,390,550$ & $3,430,350$ & $3,204,140$ & $97,029,900$ \\
\hline 4 & & & $1,940,598$ & $5,336,645$ & $3,396,047$ & $3,100,781$ & $96,059,601$ \\
\hline 5 & & & $1,921,192$ & $5,283,278$ & $3,362,086$ & $3,000,756$ & $95,099,005$ \\
\hline 6 & & & $1,901,980$ & $5,230,445$ & $3,328,465$ & $2,903,957$ & $94,148,015$ \\
\hline 7 & & & $1,882,960$ & $5,178,141$ & $3,295,181$ & $2,810,281$ & $93,206,535$ \\
\hline 8 & & & $1,864,131$ & $5,126,359$ & $3,262,229$ & $2,719,627$ & $92,274,469$ \\
\hline 9 & & & $1,845,489$ & $5,075,096$ & $3,229,606$ & $2,631,897$ & $91,351,725$ \\
\hline 10 & & & $1,827,034$ & $5,024,345$ & $3,197,310$ & $2,546,997$ & $90,438,208$ \\
\hline 11 & & & $1,808,764$ & $4,974,101$ & $3,165,337$ & $2,464,836$ & $89,533,825$ \\
\hline 12 & & & $1,790,677$ & $4,924,360$ & $3,133,684$ & $2,385,325$ & $88,638,487$ \\
\hline 13 & & & $1,772,770$ & $4,875,117$ & $3,102,347$ & $2,308,379$ & $87,752,102$ \\
\hline 14 & & & $1,755,042$ & $4,826,366$ & $3,071,324$ & $2,233,915$ & $86,874,581$ \\
\hline 15 & & & $1,737,492$ & $4,778,102$ & $3,040,610$ & $2,161,854$ & $86,005,835$ \\
\hline 16 & & & $1,720,117$ & $4,730,321$ & $3,010,204$ & $2,092,116$ & $85,145,777$ \\
\hline 17 & & & $1,702,916$ & $4,683,018$ & $2,980,102$ & $2,024,629$ & $84,294,319$ \\
\hline 18 & & & $1,685,886$ & $4,636,188$ & $2,950,301$ & $1,959,318$ & $83,451,376$ \\
\hline 19 & & & $1,669,028$ & $4,589,826$ & $2,920,798$ & $1,896,114$ & $82,616,862$ \\
\hline 20 & & & $1,652,337$ & $4,543,927$ & $2,891,590$ & $1,834,949$ & $81,790,694$ \\
\hline
\end{tabular}

